\title{
AGRICULTURAL RESIDUES AS SUBSTRATES IN THE PRODUCTION OF FORMOSA PAPAYA, OKRA AND ZUCCHINI SEEDLINGS
}

\author{
RESÍDUOS AGRÍCOLAS COMO SUBSTRATOS NA PRODUÇÃO DE MUDAS DE \\ MAMÃO FORMOSA, ABÓBORA E QUIABO
}

\section{Paola Alfonsa Vieira LO MONACO ${ }^{*}$; Larissa Ionara Silva PAULA ${ }^{2}$; Paola Honorato SALLA ${ }^{2}$; Ismail Ramalho HADDADE ${ }^{1}$; Gustavo Haddad Souza VIEIRA ${ }^{1}$; Rodrigo Júnior NANDORF ${ }^{3}$; Lillya MATTEDI ${ }^{3}$}

1. Instituto Federal do Espírito Santo, Programa de Pós-graduação em Especialização em Gestão Ambiental, campus Santa Teresa, Santa Teresa, ES. *paolalm@ifes.edu.br. 2. Instituto Federal do Espírito Santo, campus Santa Teresa, Santa Teresa, ES. 3. Instituto Federal do Espírito Santo, campus Santa Teresa, Santa Teresa, ES.

\begin{abstract}
Using residues generated in agriculture to produce seedlings is an economically interesting alternative, besides being a way to reduce the environmental impacts caused by their inadequate disposal. This study aimed to evaluate the potential of using coffee chaff (CC) and organic compost (OC) as substrate components for the production of Formosa papaya seedlings and the potential of grape pomace (GP), a vitiviniculture residue, in the composition of substrates for the production of okra and zucchini seedlings. We carried out two trials in a completely randomized design (CRD): the first had seven treatments and six replicates: T0: $100 \%$ commercial substrate Bioplant ${ }^{\circledR}(\mathrm{CS})$; from $\mathrm{T} 1$ to $\mathrm{T} 6$ : increasing proportions of $\mathrm{CC}$ and decreasing of CC: 10/90;20/80;30/70;40/60; 50/50 e 60/40\%. The second had six treatments and six replicates, with increasing proportions of GP and decreasing proportions of CS: 0/100;10/90; 20/80; 30/70; $40 / 60$ and $50 / 50 \%$.In the first trial we evaluated the number of leaves, root length, seedling height, stem diameter, shoot dry mass, root dry mass, total dry mass and Dickson Quality Index (DQI) at 59 days after sowing. The second trial was performed at 12 and 18 DAS and we analyzed the number of leaves, plant height, root length, collar diameter, shoot dry mass, root dry mass, total dry mass and Dickson Quality Index (DQI). Variables that met the assumptions of normality and homoscedasticity were subjected to Dunnett's test. The substrate composed of coffee chaff and organic compost has a high potential to be used as an alternative substrate due to promote better quality of papaya seedlings compared to the commercial substrate. Alternative substrate containing $60 \%$ coffee chaff and $40 \%$ organic compost is recommended for the production of Formosa papaya seedlings in tubes. The grape pomace (GP) has a high potential to be used as component in substrate for the production of okra and zucchini seedlings compared to the commercial substrate (CS) only. Alternative substrate composed of 50\% GP and 50\% CS is recommended for the production of zucchini seedlings, while substrate composed of $10 \%$ GP and $90 \%$ CS is recommended for the production of okra seedlings.
\end{abstract}

KEYWORDS: Coffee chaff. Organic compost. Vitiviniculture.

\section{INTRODUCTION}

The cultivation of Formosa papaya (Carica papaya) is an agricultural activity of great economic importance for the development of Brazil, especially for the economy of Espírito Santo and Bahia states, due to its high potential for generating employment and income (GALO et al., 2014).

The state of Espírito Santo, especially in the mountainous region, also has great prominence in the production of vegetables (LO MONACO et. al., 2020). The production of vegetables is one of the main sources of income for farmers in the region, especially those of family farming (ESPÍRITO SANTO, 2016). Among the vegetables produced in large quantities in the mountainous region of Espírito Santo, pumpkin and okra stand out.

Within the production chain of papaya and vegetables cultivation, the use of good quality seedlings is an extremely important factor for the success of the crop (OLIVEIRA JÚNIOR; CAIRO; NOVAES, 2011). According to Lo Monaco et al. (2020), seedling formation is one of the most important stages of the crop cycle, directly influencing the final performance of the plant, from both the nutritional and the productive points of view. According to Pereira et al. (2010), good quality seedlings presuppose adequate development and good root system formation, with better capacity to adapt to the new site after transplantation. 
One of the factors related to seedling quality is the type of substrate used. More than performing the function of supporting plants, according to Oliveira et al. (2008), substrates must have low cost, be available near the region of consumption, have sufficient contents of nutrients, good cation exchange capacity, enable aeration and moisture retention, and favor the physiological activity of the roots. In addition, a good quality substrate is an important factor in seed germination, seedling development and crop yield (DUARTE et al., 2010).

With the use of commercial substrates and additional fertilizations, the production of papaya and vegetables seedlings becomes more expensive, thus increasing the cost of production. In this perspective, in order to reduce the costs of commercial substrates, the use of residues generated in agriculture to obtain seedlings is an interesting alternative from the economic point of view, besides being a way to reduce the environmental impacts caused by their inadequate disposal (GUISOLFI et al., 2020). According to Costa et al. (2017), residues used as substrate must have satisfactory economic, ecological, physical and chemical aspects and be free of bacteria, fungi and other pathogens to ensure plant health, besides having low salinity level and good nutrient availability.

Several materials can be used as substrates for the cultivation of plant species, but it is difficult to find a single material that meets all the requirements of the species to be cultivated (SANTOS et al., 2000). In this context, it has been common to use more than one residue in the composition of a substrate.

Among the residues generated in large quantities in the state of Espírito Santo, coffee chaff stands out, generated during the drying process of coffee, and the residues of viticulture, generated in the production of grapes and wine.

Coffee chaff is composed of plant remains such as leaves, branches, remnants of inflorescences and poorly formed grains of coffee, which, when dried together with it, are burned and released from the dryer. Due to its fertilizer potential (MENEGHELLI et al., 2016), coffee chaff has been used as a component of substrates to produce seedlings of various crops, such as tomato (KRAUSE et al., 2017), coffee (MENEGHELLI et al., 2016; MENEGHELLI et al., 2018a), melon (ALMEIDA et al., 2018a), eggplant (MENEGHELLI et al., 2017), cucumber (GUISOLFI et al., 2018) and cabbage (MENEGHELLI et al., 2018b), leading to excellent results in the development and quality of these seedlings.
According to Zhang et al. (2017), after the winemaking process there are several residues such as grape pomace, stalk, wine lees and sludge. Of these materials, grape pomace is the main component, representing about $62 \%$ of the total organic waste (RUGGIERI et al., 2009), consisting mainly of peels, seeds and pulp residues (ZOCCA et al., 2007). The peels represent on average $82 \%$ of the dry weight of pomace, containing a large amount of phenolic compounds, including anthocyanins, hydroxycinnamic acids, catechins and flavonols (ROCKENBACH et al., 2011).

Often, these residues are not treated or used, having an environmentally inadequate disposal, with potential risks of contamination of soils and surface and subsurface water. On the other hand, Schaffer, Torniquist and Manfroi (2013) point out that vitiviniculture residues have the potential to be used for agricultural purposes, indicating that $\mathrm{N}$ and $\mathrm{K}$ are the nutrients present in largest amounts in these residues, which also contain very high levels of organic matter.

Thus, with the need to reduce costs with commercial substrates and take advantage of the availability of vitiviniculture residues generated in the region, some studies have been carried out with different combinations of commercial substrates and residues from the winemaking process in seedlings of vegetable and fruit crops, such as those conducted by Carmona et al. (2012) and Pinter et al. (2019). Pinter et al. (2019) evaluated the use of winemaking residue compost as substrate for lettuce, tomato, bell pepper and melon seedlings and found high potential for the use of these residues, especially when mixed with the commercial substrate. Similarly, Carmona et al. (2012) studied the use of vitiviniculture residue compost as substrates for the cultivation in ornamental plants and verified that the compost does not have limiting characteristics for use as a medium for cultivation ornamental plants in containers and can replace conventional substrates such as peat and coconut fiber.

Besides coffee chaff and vitiviniculture residues, organic compost has been widely used as a component of substrates in the production of several seedlings such as those of lettuce (SIMÕES et al., 2015; SILVA et al., 2018a), papaya (SILVA et al., 2018b), guava (COSTA et al., 2017), among others. Organic compost can be obtained by composting residues generated in the property, such as those from pruning, grasses and cattle manure, and is an excellent component due to its nutritional, physical and structural potential. Organic compost may have high concentration of nutrients such as calcium, 
Agricultural residues...

magnesium and phosphorus and adequate physical/hydraulic properties. This material also has a high cation exchange capacity and high levels of organic matter (CARDOSO et al., 2011), besides promoting the development of more vigorous seedlings (PEREIRA et al., 2012).

The use of alternative sources of agricultural or agro-industrial residues in the composition of substrates for the production of papaya e vegetables seedlings can be a solution to make both activities more sustainable and ecologically correct, as it aims to eliminate an environmental problem of agroindustry (or any properties that generate residues), because the residues are used and disposed of harmoniously in the environment, at the same time reducing the costs of papaya e vegetables production, which favors the entire chain, from producer to consumer.

Thus, according to each species, it should be verified which substrate is the best substrate, which provides the formation of better-quality plants for transplantation. In this context, it is believed that vitiviniculture and coffee processing residues can be promising components to replace part of the commercial substrate used in the production of other seedlings, such as those of papaya, pumpkin and okra, whose proportions require experimentation.

This study aimed to evaluate the potential of using coffee chaff and organic compost as substrate components for the production of Formosa papaya seedlings and the potential of vitiviniculture residues in the composition of substrates for the production of okra and zucchini seedlings.

\section{MATERIAL AND METHODS}

\section{Production of papaya seedlings}

The experiment was installed and conducted in the Seedling Production nursery of IFES, Campus
LO MONACO, P. A. V. et al.

of Santa Teresa, ES, Brazil, at geographic coordinates: $19^{\circ} 48^{\prime} 13^{\prime \prime} \mathrm{S}$ latitude, $40^{\circ} 40^{\prime} 42^{\prime \prime} \mathrm{W}$ longitude and average altitude of $127 \mathrm{~m}$, in an environment protected by $80 \%$ shade net, in the period from February to April 2019. The crop used in the experiment was Formosa papaya (Carica papaya).

The residues used as components of the alternative substrate were coffee chaff and organic compost. The coffee chaff came from the processing of Coffea canephora cultivated in the municipality of Santa Teresa, Espírito Santo, and was used as it was collected, that is, without any crushing or sieving treatment. The commercial substrate used was Bioplant ${ }^{\circledR}$, which is composed of coconut fiber, pine bark and vermiculite. The organic compost was produced from the decomposition of crop residues, crotalaria and cattle manure.

Chemical and physicochemical characterization (electrical conductivity) of coffee chaff and organic compost was performed at the Water and Solid Waste Quality Laboratory of IFES, Santa Teresa Campus, following the methodology described by Matos (2015). Chemical analysis consisted of the determination of $\mathrm{pH}$, with a benchtop $\mathrm{pH}$ meter, and the quantification of the concentrations of easily oxidizable organic carbon $\left(\mathrm{OC}_{\mathrm{EO}}\right)$, total organic carbon $\left(\mathrm{OC}_{\mathrm{T}}\right)$, total nitrogen $\left(\mathrm{N}_{\mathrm{T}}\right)$, organic nitrogen $\left(\mathrm{N}_{\mathrm{ORG}}\right)$, total phosphorus $\left(\mathrm{P}_{\mathrm{T}}\right)$, potassium $(\mathrm{K})$ and carbon/nitrogen ratio $(\mathrm{C} / \mathrm{N})$. Physicochemical analysis consisted of the determination of electrical conductivity (EC), using a benchtop conductivity meter, in the proportion of $10 \mathrm{~cm}^{3}: 25 \mathrm{~cm}^{3}$ (v:v). Table 1 shows the chemical and physicochemical (EC) attributes of the coffee chaff and organic compost used as alternative substrate components.

Table 1. Chemical and physicochemical (EC) attributes of the coffee chaff (CC) and organic compost (OC) used as substrate components in the experiment.

\begin{tabular}{|c|c|c|c|c|c|c|c|c|c|}
\hline Residue & $\mathrm{pH}$ & $\begin{array}{c}\text { EC } \\
\mathrm{dS} \mathrm{m}^{-1}\end{array}$ & $\mathrm{OC}_{\mathrm{EO}}$ & $\mathrm{OC}_{\mathrm{T}}$ & $\begin{array}{c}\mathrm{N}_{\mathrm{T}} \\
---\mathrm{dag}\end{array}$ & $\mathrm{N}_{\mathrm{ORG}}$ & $\mathrm{P}_{\mathrm{T}}$ & $\mathrm{K}$ & $\mathrm{C} / \mathrm{N}$ \\
\hline $\mathrm{CC}$ & 5.60 & 6.49 & 31.74 & 41.26 & 2.31 & 2.07 & 0.14 & 0.71 & 17.86 \\
\hline $\mathrm{OC}$ & 6.9 & 6.00 & - & - & 0.55 & - & 1.21 & 0.28 & 15.00 \\
\hline
\end{tabular}

${ }^{1} \mathrm{pH}$ - hydrogen potential in water; $\mathrm{EC}$ - electrical conductivity 1:2.5 (v:v); $\mathrm{OC}_{\mathrm{EO}}$-easily oxidizable organic carbon; $\mathrm{OC}_{\mathrm{T}^{-}}$total organic carbon; $\mathrm{N}_{\mathrm{T}}$-total nitrogen; $\mathrm{P}_{\mathrm{T}}$-total phosphorus; $\mathrm{K}$ - potassium; $\mathrm{C} / \mathrm{N}$ - carbon/nitrogen ratio.

The experimental design adopted was completely randomized, with seven treatments and six replicates. Each experimental unit consisted of 24 (twenty-four) seedlings, totaling 1,008 (one thousand and eight) seedlings in the entire experiment.
Table 2 shows the proportions of coffee chaff (CC), organic compost (OC) and commercial substrate (CS) used in the different treatments, as alternative substrates in the production of Formosa papaya seedlings. 
Table 2. Description of treatments (T0 to T6), with different proportions of coffee chaff (CC), organic compost (OC) and commercial substrate (CS).

\section{TREATMENT}

T0

$\mathrm{T} 1$

$\mathrm{T} 2$

T3

T4

T5

T6

$$
\begin{aligned}
& \text { COMPOSITION } \\
& 0 \% \mathrm{CC}+0 \% \mathrm{OC}+100 \% \mathrm{CS} \\
& 90 \% \text { OC }+10 \% \mathrm{CC} \\
& 80 \% \text { OC }+20 \% \mathrm{CC} \\
& 70 \% \text { OC }+30 \% \mathrm{CC} \\
& 60 \% \text { OC }+40 \% \mathrm{CC} \\
& 50 \% \text { OC }+50 \% \mathrm{CC} \\
& 40 \% \text { OC }+60 \% \mathrm{CC}
\end{aligned}
$$

The T0 treatment was considered in the present study as the conventional treatment, because the commercial substrate was the traditional one used by the producers of papaya seedlings in tubes.

The seedlings were arranged in trays with capacity for 96 tubes. Eighteen border seedlings were considered for each replicate. Thus, the 6 central seedlings of the row were evaluated, in a total of 252 (two hundred and fifty-two) seedlings evaluated in the experiment.

The seeds used in this study were those of the Formosa papaya cultivar "Tainung", which has higher germination percentage. The seeds were arranged in $290 \mathrm{~cm}^{3}$ plastic tubes, one seed per tube, containing the different treatments. Irrigation was performed daily, maintaining the substrates at field capacity.

The experiment lasted 59 days, with evaluations following agronomic characteristics: number of leaves, seedling height and stem diameter, whereas the gravimetric variables evaluated were shoot dry mass, root dry mass and total dry mass. In addition to these variables, the Dickson Quality Index (DQI) was also determined.

Shoot height was measured with a ruler, from the base of the collar to the apical bud originating the last leaf. Root length was measured using a ruler from the collar to the tip of the root. Stem diameter was obtained using a precision digital caliper. For shoot dry mass determination, the shoots were collected by cutting the seedlings near the substrate, while for root dry mass determination, the roots were carefully washed in running water, on a sieve. Subsequently, the materials were placed in paper bags, dried in a forced air circulation oven at $65^{\circ} \mathrm{C}$ for 72 hours, and then weighed on an electronic scale with $0.01 \mathrm{~g}$ accuracy.

Dickson quality index (DQI) was determined as a function of shoot height $(\mathrm{H})$, stem diameter (SD), total dry mass (TDM), shoot dry mass (SDM) and root dry mass (RDM), using Equation 1 (DICKSON; LEAF; HOSNER, 1960):

$$
\mathrm{DQI}=\frac{\mathrm{TDM}}{\frac{\mathrm{H}}{\mathrm{SD}}+\frac{\mathrm{SDM}}{\mathrm{RDM}}}
$$

where:

$\mathrm{DQI}=$ Dickson quality index,

TDM $=$ total dry mass $(\mathrm{g})$,

$\mathrm{H}=$ shoot height $(\mathrm{cm})$,

$\mathrm{SD}=$ stem diameter $(\mathrm{mm})$,

$\mathrm{SDM}=$ shoot dry mass $(\mathrm{g})$,

$\mathrm{RDM}=$ root dry mass $(\mathrm{g})$.

To verify the normality of the data and homoscedasticity of variances, the data were subjected to normality (Lilliefors) and homoscedasticity (Bartlett) tests, assumptions for the analysis of variance. For variables that met the assumptions, the treatments were compared one by one with the control, using the Dunnett Test. An " $\alpha$ " equal to 0.05 was adopted for all procedures. The statistical procedures were carried out using the $\mathrm{R}$ studio software (R Development Core Team, 2019).

\section{Production of okra and zucchini seedlings}

The experiment was installed and conducted from August 2018 to July 2019, in the seedling production nursery at the Federal Institute of Espírito Santo - Campus of Santa Teresa, Espírito Santo, Brazil. The vegetables used in the experiments were okra (Abelmoschuss esculentus) and pumpkin (Cucurbita moschata).

The residue used in the alternative substrate for the production of vegetable seedlings came from winemaking process, being called "grape pomace" GP, which consists of peel (epidermis) and seeds of Granod'Oro grape (Vitis labrusca), clone of the Ives noir variety. The residue was collected at the "Cantina Matiello" winery, located in the 
municipality of Santa Teresa, Espírito Santo state, Brazil. The pomace was only dried in the sun and crushed in an industrial blender before mixing, with no sieving.

Chemical and physicochemical characterization of GP was performed in the Water Quality and Solid Waste Laboratory of IFES, Campus of Santa Teresa, following the methodology described by Matos (2015). Chemical analysis consisted of the determination of $\mathrm{pH}$, using a benchtop $\mathrm{pH}$ meter, and quantification of the concentrations of easily oxidizable organic carbon $\left(\mathrm{OC}_{\mathrm{EO}}\right)$, total nitrogen $\left(\mathrm{N}_{\mathrm{TOTAL}}\right)$ and phosphorus $(\mathrm{P})$. Physicochemical analysis consisted of the determination of electrical conductivity (EC), using a benchtop conductivity meter, in the proportion of $10 \mathrm{~cm}^{3}: 25 \mathrm{~cm}^{3}$ (v:v). Table 3 shows the chemical and physicochemical characterization of grape pomace.

Table 3. Chemical and physicochemical characterization of grape pomace.

\begin{tabular}{|c|c|c|c|c|}
\hline \multirow[t]{2}{*}{$\mathrm{pH}$} & $\mathrm{EC}$ & $\mathrm{OC}_{\mathrm{EO}}$ & $\mathrm{N}_{\mathrm{ammoniacal}}$ & $\mathrm{P}_{\text {TOTAL }}$ \\
\hline & $\mathrm{dS} \mathrm{m}{ }^{-1}$ & \multicolumn{3}{|c|}{ 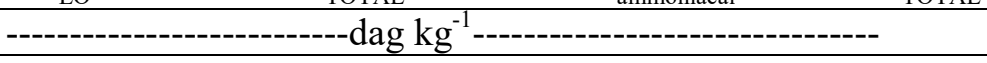 } \\
\hline 3.4 & 3.15 & 36.69 & 1.84 & 0.396 \\
\hline
\end{tabular}

The experimental design adopted was completely randomized, with six treatments and six replicates. Each replicate consisted of 20 (twenty) seedlings, totaling 720 (seven hundred and twenty) seedlings for each vegetable.

Sowing was carried out in isopropylene trays with 200 cells, by placing 1 seed per cell at 1 $\mathrm{cm}$ depth. Irrigation was performed daily with a watering can.
Each replicate had 12 border seedlings, 6 on each side, with evaluations in the 8 central seedlings of the row, in a total of 288 (two hundred and eighty-eighty) seedlings for each vegetable.

The experiments carried out for the two vegetables studied consisted of the application of the treatments presented in Table 4.

Table 4. Description of treatments (T0 to T5), with different proportions of grape pomace (GP), and commercial substrate (CS).

$\begin{array}{cc}\text { TREATMENT } & \text { COMPOSITION } \\ \text { T0 } & 0 \% \text { of grape pomace }(\mathrm{GP})+100 \% \text { of Commercial Substrate }(\mathrm{CS}) \text { - control; } \\ \text { T1 } & 10 \% \mathrm{GP}+90 \% \mathrm{CS} \\ \text { T2 } & 20 \% \mathrm{GP}+80 \% \mathrm{CS} \\ \text { T3 } & 30 \% \mathrm{GP}+70 \% \mathrm{CS} \\ \text { T4 } & 40 \% \mathrm{GP}+60 \% \mathrm{CS} \\ \text { T5 } & 50 \% \mathrm{GP}+50 \% \mathrm{CS}\end{array}$

The treatment T0 (commercial substrate) was considered as the control treatment, because it is traditionally used by vegetable producers in the region. The substrate used was Plantmax ${ }^{\circledR}$, whose chemical characteristics are presented in Table 5.

Table 5. Chemical characteristics of the Plantmax ${ }^{\circledR}$ substrate used in the experiment.

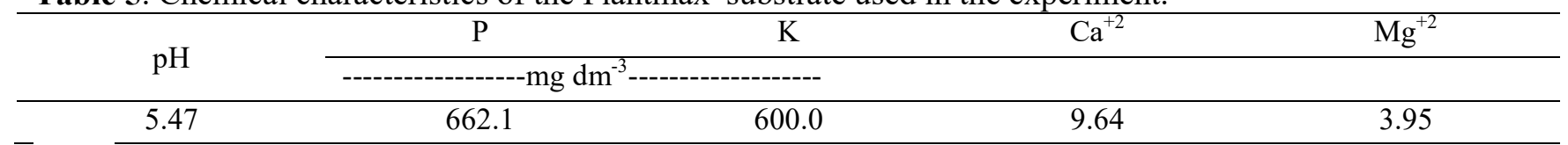

Source: Wagner Júnior et al. (2008).Where: $\mathrm{pH}$ - hydrogen potential in water; $\mathrm{P}$ - phosphorus; $\mathrm{K}$ - potassium; $\mathrm{Ca}-\mathrm{calcium}$ and $\mathrm{Mg}-$ magnesium

In the experiment with pumpkin, the seedlings were produced from seeds of the cultivar 'Menina Brasileira' and evaluated 12 days after sowing (DAS).Okra was obtained from seeds of the cultivar 'Santa Cruz 47', evaluated at 18 DAS.

As biometric variables, the number of leaves, plant height, root length, collar diameter, 
Agricultural residues...

shoot dry mass and root dry mass were evaluated. Among the gravimetric analyses, shoot dry mass, root dry mass and total dry mass were evaluated. In addition to these variables, the Dickson Quality Index (DQI) was also determined.

Lengths and collar diameter were obtained using a millimeter ruler and a precision digital caliper, respectively. Each seedling was divided into shoots and roots by a cut in the collar. To obtain root dry mass, roots were carefully washed and subsequently placed in paper bags and dried in a forced air circulation oven at $65{ }^{\circ} \mathrm{C}$ for 72 hours. Then, the materials were weighed on an electronic scale with precision of $0.01 \mathrm{~g}$. Biometric and gravimetric analyses were conducted at the Water quality and Solid Waste Laboratory of IFES Campus Santa of Teresa.

Dickson quality index (DQI) was determined as a function of shoot height $(\mathrm{H})$, collar diameter (CD), shoot dry mass (SDM) and root dry mass (RDM), using Equation 1 (Dickson et al., 1960), previously presented.

All variables evaluated were subjected to normality (Shapiro-Wilk) and homoscedasticity (Levene) tests, required for validating their analyses
LO MONACO, P. A. V. et al.

of variance. The variables that met the assumptions of normality and homoscedasticity were subjected to the Dunnett's test, while those that did not meet the assumptions were subjected to the signal test. For all procedures, " $\alpha$ " equal to 0.05 was adopted. The statistical procedures were performed using the software R studio (R Core Team, 2019).

\section{RESULTS AND DISCUSSION}

\section{Production of papaya seedlings}

In general, all variables analyzed, in all treatments, showed higher and statically significant values $(\mathrm{P}>0.05)$ compared to the control (commercial substrate), except for root len (RL), root dry mass (RDM) and Dickson Quality Index (DQI). For the variables RL and RDM, the treatment with $10 \%$ coffee chaff and $90 \%$ organic compost showed no statistical difference $(\mathrm{P}<0.05)$ when compared to the control. For DQI, the treatments T4 (40/60) andT6 (60/40) also showed no statistical difference $(\mathrm{P}<0.05)$ when compared to the control (Table 6).

Table 6. Means of the variables analyzed in the substrate (EC) and in Formosa papaya seedlings, in response to treatments containing increasing levels of coffee chaff and decreasing levels of organic compost, besides the commercial substrate (control), in Formosa papaya seedlings, at 59 DAS.

\begin{tabular}{|c|c|c|c|c|c|c|c|c|c|}
\hline \multirow[b]{2}{*}{ Variables } & \multicolumn{7}{|c|}{ TREATMENTS } & \multirow[b]{2}{*}{$P$ value } & \multirow[b]{2}{*}{$\mathrm{CV}$} \\
\hline & $\begin{array}{l}\text { Control } \\
\text { (T0) }\end{array}$ & $\begin{array}{l}10 / 90 \\
\text { (T1) }\end{array}$ & $\begin{array}{l}20 / 80 \\
(\mathrm{~T} 2)\end{array}$ & $\begin{array}{l}30 / 70 \\
\text { (T3) }\end{array}$ & $\begin{array}{l}40 / 60 \\
\text { (T4) }\end{array}$ & $\begin{array}{l}50 / 50 \\
\text { (T5) }\end{array}$ & $\begin{array}{l}60 / 40 \\
\text { (T6) }\end{array}$ & & \\
\hline $\mathrm{EC}\left(\mathrm{dS} \cdot \mathrm{m}^{-1}\right)$ & $0.0550 \mathrm{~b}$ & $0.3283 a$ & $0.2216 \mathrm{a}$ & $0.2500 \mathrm{a}$ & $0.2900 \mathrm{a}$ & $0.3583 \mathrm{a}$ & $0.3233 a$ & 0.0000 & $17.28 \%$ \\
\hline $\mathrm{RL}(\mathrm{cm})$ & $12.68 \mathrm{~b}$ & $13.26 \mathrm{~b}$ & $15.71 \mathrm{a}$ & $15.06 \mathrm{a}$ & $15.18 \mathrm{a}$ & $14.46 \mathrm{a}$ & $15.74 \mathrm{a}$ & 0.0000 & $5.53 \%$ \\
\hline $\mathrm{H}(\mathrm{cm})$ & $13.22 \mathrm{~b}$ & $23.73 \mathrm{a}$ & $25.99 \mathrm{a}$ & $26.13 \mathrm{a}$ & $25.86 \mathrm{a}$ & $26.16 \mathrm{a}$ & $25.66 \mathrm{a}$ & 0.0000 & $6.05 \%$ \\
\hline $\mathrm{SD}(\mathrm{mm})$ & $4.66 \mathrm{~b}$ & $6.64 \mathrm{a}$ & $7.38 \mathrm{a}$ & $7.16 \mathrm{a}$ & $7.16 \mathrm{a}$ & $7.19 \mathrm{a}$ & $6.78 \mathrm{a}$ & 0.0000 & $7.90 \%$ \\
\hline NL (un) & $4.92 \mathrm{~b}$ & $5.72 \mathrm{a}$ & $5.69 \mathrm{a}$ & $5.69 \mathrm{a}$ & $5.94 \mathrm{a}$ & $6.11 \mathrm{a}$ & $6.27 \mathrm{a}$ & 0.0000 & $5.00 \%$ \\
\hline $\operatorname{SDM}(\mathrm{g})$ & $1.83 \mathrm{~b}$ & $3.32 \mathrm{a}$ & $4.03 \mathrm{a}$ & $3.73 \mathrm{a}$ & $3.31 \mathrm{a}$ & $3.75 \mathrm{a}$ & $3.30 \mathrm{a}$ & 0.0000 & $15.06 \%$ \\
\hline RDM (g) & $0.98 \mathrm{~b}$ & $1.00 \mathrm{~b}$ & $2.52 \mathrm{a}$ & $2.45 a$ & $2.51 \mathrm{a}$ & $2.37 \mathrm{a}$ & $2.30 \mathrm{a}$ & 0.0000 & $12.49 \%$ \\
\hline DQI & $0.59 \mathrm{~b}$ & $0.63 \mathrm{a}$ & $1.28 \mathrm{a}$ & $1.19 \mathrm{a}$ & $1.18 \mathrm{~b}$ & $1.17 \mathrm{a}$ & $1.08 \mathrm{a}$ & $1.49 \mathrm{E}-06$ & $13.83 \%$ \\
\hline
\end{tabular}

*RL - root length; H - seedling height; SD - stem diameter; NL - number of leaves; EC - electrical conductivity; RDM - root dry mass; SDM - shoot dry mass; DQI - Dickson Quality Index; **Lowercase letters in each rows compare each of the treatments with the control, by Dunnett test at $5 \%$ probability level.

Electrical conductivity in the substrate is an important variable to estimate the availability of salts present in the medium. The treatment with the highest EC values was the one containing $50 \%$ coffee chaff and $50 \%$ organic compost (T5) (Table 6). Meneghelli et al. (2016), using coffee chaff as an alternative substrate for the production of Conilon coffee seedlings, also found higher values of electrical conductivity in substrates containing higher proportions of coffee chaff, which negatively influenced the variables analyzed. In the present study, however, the highest value obtained does not pose risks of causing damage to the development of papaya seedlings. Cavins et al. (2000) classify EC into levels: very low $\left(0\right.$ to $\left.0.25 \mathrm{dS} \mathrm{m}^{-1}\right)$, low $(0.26$ to $\left.0.75 \mathrm{dS} \mathrm{m}^{-1}\right)$,normal $\left(0.76\right.$ to $\left.1.25 \mathrm{dS} \mathrm{m}^{-1}\right)$, high (1.26 to $\left.1.75 \mathrm{dSm}^{-1}\right)$, very high (1.76 to $2.25 \mathrm{dS} \mathrm{m}^{-1}$ ) and extreme (above $2.25 \mathrm{dS} \mathrm{m}^{-1}$ ). In this case, the 
highest value reached $\left(0.358 \mathrm{dS} \mathrm{m} \mathrm{m}^{-1}\right)$, due to the highest proportion of coffee chaff (60/40), is within the range considered low.

For root length, the treatment containing the highest proportion of coffee chaff $(60 \%)$ and $40 \%$ of organic composted to an average approximately $24 \%$ higher than that of the control (Table 6). This characteristic is of great importance for the quality of a seedling, since a longer root system can explore larger areas in the soil, with greater possibilities of acquiring nutrients (SOUSA, 2010).

Plant height is a very important variable in the production process, as it is one of the main factors in the decision to remove seedlings from the greenhouse for commercialization. According to Berilli et al. (2011), the possibility of marketing seedlings in a shorter time represents saving of time and resources, without loss of quality. According to Table 6 , the treatment containing $50 \%$ of each residue led to the highest mean value of seedling height, being approximately 95\% higher than the mean value obtained in the control. In addition, the results obtained for seedling height in this study $(23.73$ to $26.16 \mathrm{~cm})$, for any of the treatments containing increasing levels of coffee chaff and decreasing levels of organic compost, were higher than those obtained by other authors, who also evaluated seedlings of Formosa papaya. Costa Júnior et al. (2017), evaluating the production of Formosa papaya seedlings with different proportions of moriche palm (Mauritia flexuosa L.) and organic compost, did not obtain seedling height values greater than $19.37 \mathrm{~cm}$, at 65 DAS. Almeida et al. (2018b), evaluating the quality of papaya seedlings at 60 DAS, grown in alternative substrates, obtained heights between 11.41 and $19.67 \mathrm{~cm}$. Oliveira et al. (2015) did not obtain height greater than $19.32 \mathrm{~cm}$ in plants cultivated in a sheep manure-based substrate. Even in the study conducted by Guimarães et al. (2015), in which the parameters of seedling quality should have values clearly higher as the authors evaluated the influence of growth inducer on different papaya accessions, the heights ranged from 21.47 to $26.54 \mathrm{~cm}$, values that are similar to those obtained in the present study. Mendonça et al. (2007), studying different levels of organic compost in the formulation of substrate for the production of Formosa papaya seedlings, verified lower plant heights in substrates with absence of organic compost and higher values in substrate containing $40 \%$ of organic compost. The authors justified that this influence on plant growth can be attributed to the application of organic matter, which, in addition to phosphorus, an important element for papaya, is a supplier of other important nutrients such as nitrogen and sulfur.

According to Smiderle and Souza (2016), stem diameter is one of the most important morphological traits to estimate seedling growth after planting in the field. All alternative treatments led to stem diameter values from 43 to $58 \%$ higher than that of the control. In addition, the results obtained in this study (6.64 to $7.38 \mathrm{~mm}$ ) were also higher than those obtained by Costa Junior et al. (2017), who obtained a maximum SD of $5 \mathrm{~mm}$, and by Almeida et al. (2018b), who obtained a maximum SD of $5.51 \mathrm{~mm}$, in Formosa papaya seedlings, at similar DAS. Oliveira et al. (2015), analyzing the production of Formosa papaya seedlings under different doses of sheep manure, found that plants fertilized with $60 \%$ manure showed a $146.2 \%$ increase in SD in comparison to those that were not fertilized with manure, demonstrating that the use of organic substrates is an interesting alternative in the production of Formosa papaya seedlings. The authors did not obtain SD greater than $6 \mathrm{~mm}$, although the seedlings were evaluated earlier (40 DAS) compared to this study (59 DAS).

The number of leaves is related to the leaf area of a seedling, which is indicative of yield, biomass production and plant quality during the crop cycle (WERADUWAGE et al., 2010). In this study, the alternative treatments led to mean number of leaves about 16 to $29 \%$ higher than that of the control. The results obtained in this study were relatively lower than those obtained by Silva et al. (2018b), in the Midwest region, who evaluated the formation of papaya seedlings in different organic substrates and found a maximum number of leaves of 7.8 leaves, at 90 DAS. Similarly, the results were also lower than those obtained in the Northeast region by Costa Júnior et al. (2017), who found values between 6 and 9 units at 65 DAS, and those obtained also in the Northeast region by Oliveira et al. (2015), who observed values between 5 and 11 units, approximately, at 40 DAS. This may be related to the climatic conditions of the regions where the above-mentioned studies were carried out because, as these regions have higher average temperature, the quality and intensity of light influence the development of the plant. According to Schock et al. (2014), the light conditions become of paramount importance in the development, growth and production of plants.

All alternative treatments promoted shoot dry mass values from 81 to $220 \%$ higher than that of the control $(\mathrm{P}>0.05)$. These results are superior to those found by Costa Júnior et al. (2017), who 
Agricultural residues...

studied the growth of Formosa papaya seedlings in substrates based on moriche palm residues and reached a maximum value of $1.5 \mathrm{~g}$ at $65 \mathrm{DAS}$, and those reported by Almeida et al. (2018b), who did not find SDM values higher than $0.82 \mathrm{~g}$, at $60 \mathrm{DAS}$, in papaya seedlings grown in organic waste-based substrates.

Similarly, the treatments $\mathrm{T} 1$ to $\mathrm{T} 6$ led to RDM values that were 113 to $260 \%$ higher than that of the control (Table 6). The results obtained by any of the alternative treatments were higher than the maximum found by Costa Júnior et al. (2017) at 65 DAS (1.2 g), Oliveira et al. (2015) at 40 DAS (0.4 $\mathrm{g})$ and Almeida et al. (2018b) at $60 \mathrm{DAS}$ (0.26 g), in Formosa papaya seedlings.

Dickson Quality Index is an important tool, because its calculation considers parameters that evaluate the robustness and biomass distribution balance of the plant (ARAÚJO et al., 2016).

According to Table 6, all treatments containing different proportions of coffee chaff and organic compost led to higher values of DQI compared to the control, between 0.63 and 1.28. These results were higher than those obtained in several studies with Formosa papaya seedlings, at similar time (DAS). Costa Júnior et al. (2017) obtained a maximum value of 0.55 in papaya seedlings produced in substrates based on soil and moriche palm. Salles et al. (2019) did not obtain DQI higher than 0.34 in papaya seedlings at 65 days in substrates composed of soil, cattle manure, sand, vermiculite and commercial substrate. In a study carried out by Almeida et al. (2018b), evaluating the DQI in papaya seedlings grown in different substrates based on residues, the authors did not obtain values higher than 0.16 .

In general, the results obtained in this study show the beneficial effect of the organic compost when used together with the coffee chaff. This combination enables the use of a higher proportion of coffee chaff because, when it was used with other materials in the composition of an alternative substrate, it led to seedlings with good quality only when present in smaller proportions, as verified by Krause et al. (2017), Guisolfi et al. (2018), Meneghelli et al. (2017; 2018a), Lo Monaco et al. (2018), Almeida et al. (2018a), among others.

The higher values obtained in this study with the alternative substrate can be attributed to the high availability of nutrients, especially the nitrogen present in the coffee chaff (Table 1). According to Taiz and Zeiger (2013), nitrogen is considered one of the most relevant elements for increasing production, because it influences the rate of emergence rate and expansion of leaf area. Studies
LO MONACO, P. A. V. et al.

carried out by Pinheiro et al. (2017) and Oliveira et al. (2018) found that nitrogen significantly influenced root dry mass and number of leaves in papaya seedlings. In addition, according to Gimenes et al. (2017), low nitrogen availability can influence root development, production of photoassimilates and growth rate as a whole, and may alter the structural characteristics of plants.

In the case of organic compost, the presence of phosphorus stands out (Table 1) as it is another essential element for papaya growth and development. According to Taiz and Zeiger (2013), phosphorus is essential in the Calvin-Benson cycle for the formation of triose-phosphate and consequently for the synthesis of starch and sucrose for biomass formation and plant growth. Saraiva et al. (2011) reinforce the fundamental role of phosphorus in root development, water use efficiency and nutrient absorption and utilization. The effect of phosphorus on the growth of papaya seedlings has been verified in the studies conducted by Melo et al. (2007), Saraiva et al. (2011) and Souza et al. (2015).

In addition, the organic compost is rich in organic matter and, according to Cunha; Mendes and Giongo (2015), organic matter is considered one of the most useful indicators for soil quality evaluation, because its interaction with various soil components exerts direct effect on water retention, aggregate formation, soil density, $\mathrm{pH}$, buffering capacity, cation exchange capacity, mineralization, infiltration and microbial activity.

Considering the importance of DQI as relevant variable in the choice of the most adequate substrate and also that all treatments containing increasing proportions of coffee chaff and decreasing proportions of organic compost promoted higher DQI values than the commercial substrate, the substrate containing organic compost $(40 \%)$ with the highest proportion of coffee chaff $(60 \%)$ is recommended, because the latter residue is available in greater quantities in coffee producing regions. Thus, besides giving a more sustainable destination for this residue, the use of an alternative substrate containing $60 \%$ of coffee chaff and $40 \%$ of organic compost, in place of the single use of commercial substrate, enables greater saving for the producer of papaya seedlings, because it contributes to the reduction of production costs.

\section{Production of okra and zucchini seedlings}

The variables root length (RL), number of leaves (NL), root dry mass (RDM), Dickson Quality Index (DQI) and plant height (PH) in pumpkin seedlings did not show significant difference 
$(\mathrm{P}>0.05)$ in each of the treatments with increasing levels of GP in comparison to the control (T0). For collar diameter (CD), although there was significant difference $(\mathrm{P}<0.05)$ between $\mathrm{T} 3$ and $\mathrm{T} 0$, the treatments with higher proportions of GP (T4 and T5) did not differ from the control (Table 7).

Table 7. Means of the variables analyzed in pumpkin seedlings and substrate, at 12 DAS, as a function of treatments containing increasing levels of grape pomace/decreasing levels of commercial substrate (T1 to T5) and the exclusive use of commercial substrate (T0).

\begin{tabular}{|c|c|c|c|c|c|c|c|c|c|c|}
\hline $\begin{array}{l}\text { TREATMENTS } \\
\text { GP/CS }\end{array}$ & $\begin{array}{l}\mathrm{RL} \\
(\mathrm{cm})\end{array}$ & NL & $\begin{array}{l}\text { SDM } \\
(\mathrm{mg})\end{array}$ & $\begin{array}{l}\text { RDM } \\
(\mathrm{mg})\end{array}$ & $\begin{array}{l}\text { TDM } \\
(\mathrm{g})\end{array}$ & DQI & $\begin{array}{l}\mathrm{PH}^{*} \\
(\mathrm{~cm})\end{array}$ & $\begin{array}{l}\mathrm{CD}^{*} \\
(\mathrm{~mm})\end{array}$ & $\mathrm{pH}^{*}$ & $\begin{array}{l}\text { EC* } \\
\left(\mathrm{dS} \mathrm{m}^{-1}\right)\end{array}$ \\
\hline $0 / 100 \%$ (T0) & 6.85 & $3.22 \mathrm{~A}$ & $155.76 \mathrm{~A}$ & $56.68 \mathrm{~A}$ & $0.21 \mathrm{~A}$ & $0.0343 \mathrm{~A}$ & $9.95 \mathrm{~A}$ & $2.88 \mathrm{~A}$ & $5.26 \mathrm{~B}$ & $0.188 \mathrm{~B}$ \\
\hline $10 / 90 \%$ (T1) & 7.89 & $3.42 \mathrm{~A}$ & $152.03 \mathrm{~A}$ & $67.35 \mathrm{~A}$ & $0.22 \mathrm{~A}$ & $0.0391 \mathrm{~A}$ & $9.53 \mathrm{~A}$ & $2.84 \mathrm{~A}$ & $5.48 \mathrm{~A}$ & $0.190 \mathrm{~B}$ \\
\hline 20/80\% (T2) & 7.69 & $3.17 \mathrm{~A}$ & $131.33 \mathrm{~B}$ & $55.51 \mathrm{~A}$ & $0.19 \mathrm{~B}$ & $0.0323 \mathrm{~A}$ & $8.91 \mathrm{~A}$ & $2.56 \mathrm{~A}$ & $6.30 \mathrm{~A}$ & $0.366 \mathrm{~A}$ \\
\hline $30 / 70 \%$ (Т3) & 8.02 & $3.14 \mathrm{~A}$ & 117.27 B & $52.71 \mathrm{~A}$ & $0.17 \mathrm{~B}$ & $0.0308 \mathrm{~A}$ & $7.93 \mathrm{~A}$ & $2.43 \mathrm{~B}$ & $6.90 \mathrm{~A}$ & $0.390 \mathrm{~A}$ \\
\hline $40 / 60 \%$ (T4) & 8.11 & $3.25 \mathrm{~A}$ & $129.42 \mathrm{~B}$ & $55.11 \mathrm{~A}$ & $0.18 \mathrm{~B}$ & $0.0318 \mathrm{~A}$ & $9.04 \mathrm{~A}$ & $2.66 \mathrm{~A}$ & $7.02 \mathrm{~A}$ & $0.444 \mathrm{~A}$ \\
\hline $50 / 50 \%$ (T5) & 7.53 & $3.14 \mathrm{~A}$ & $117.61 \mathrm{~B}$ & $49.09 \mathrm{~A}$ & $0.17 \mathrm{~B}$ & $0.0298 \mathrm{~A}$ & $8.43 \mathrm{~A}$ & $2.70 \mathrm{~A}$ & $7.42 \mathrm{~A}$ & $0.794 \mathrm{~A}$ \\
\hline$P$ value & 0.4279 & 0.0002 & 0 & 0.0099 & 0 & 0.0199 & 0.002 & 0.005 & 0 & 0.002 \\
\hline $\mathrm{CV}$ & $14.46 \%$ & $5.81 \%$ & $9.70 \%$ & $13.93 \%$ & $0.00 \%$ & $13.95 \%$ & $7.41 \%$ & $5.55 \%$ & $3.82 \%$ & $35.06 \%$ \\
\hline
\end{tabular}

*Uppercase letters in each column compare each of the treatments with the control by Dunnett's test at 5\% probability level.

*Uppercase letters in each column compare each of the treatments with the control by the signal test at $5 \%$ probability level (response variables that did not meet mainly the assumption of homoscedasticity).

Regarding the variables shoot dry mass (SDM) and total dry mass (TDM), only the treatment $\mathrm{T} 1$ did not differ from the control $(\mathrm{P}>0.05)$. From $\mathrm{T} 2$ to $\mathrm{T} 6$, these variables were statistically lower $(\mathrm{P}<0.05)$ when each treatment containing increasing levels of GP was compared with the control (T0).

The increment in GP increased electrical conductivity (EC) in the substrate, which reached the highest value in the $50 \%$ proportion (Table 7). This behavior was already expected due to the high electrical conductivity of the residue (Table 3 ). According to Cavins et al. (2000), a substrate with EC between 0.76 and $1.25 \mathrm{dS} \mathrm{m}^{-1}$ has adequate salinity for the development of most crops. The same authors classify EC into the following levels: very low ( 0 to $\left.0.25 \mathrm{dS} \mathrm{m}^{-1}\right)$, low ( 0.26 to $0.5 \mathrm{dS} \mathrm{m}^{-}$ $\left.{ }^{1}\right)$, normal $\left(0.76\right.$ to $\left.1.25 \mathrm{dS} \mathrm{m}^{-1}\right)$, high (1.26 to 1.75 $\left.\mathrm{dS} \mathrm{m}{ }^{-1}\right)$, very high (1.76 to $2.25 \mathrm{dS} \mathrm{m}^{-1}$ ) and extreme (above $2.25 \mathrm{dS} \mathrm{m}^{-1}$ ). In this case, it can be said that values found in all treatments, even in T5, does not provide risks of causing damage to seedling development.

In general, most of the variables analyzed did not differ statistically from the control when the highest proportion of GP was used in the substrate composition. Among the variables analyzed that did not differ, DQI stands out, which is one of the most used indices to evaluate seedling quality, as it takes into account shoot, root and total dry mass productions, plant height and collar diameter (DICKSON; LEAF; HOSNER, 1960).

Another important variable in the evaluation of seedling quality is root length. According to
Echer et al. (2007), there is a direct relationship between the amount of roots and nutrients available, in the time between transplantation and the formation of new roots. When transplanted to the field with some restriction in root system development, seedlings have difficulty compensating for evapotranspiration, even if water is supplied in sufficient quantities for good development of the plants. Thus, as these two variables, which are important in the evaluation of seedling quality, did not differ with the increment of grape pomace in the composition, the substrate containing $50 \% \mathrm{GP}+50 \% \mathrm{CS}$ can be recommended for the production of pumpkin seedlings, when compared to the exclusive use of commercial substrate (T0).

Higuti et al. (2010), when evaluating the production of pumpkin seedlings 'Menina Brasileira', at 18 DAS, in a substrate based on coconut fiber with different doses of nitrogen and potassium in fertigation, obtained plant heights ranging from 6 to $9 \mathrm{~cm}$ and number of leaves from 2.2 to $2.7 \mathrm{un}$. These values are close to or even lower than (in the case of the number of leaves) than those obtained in the present study.

For okra crop, plant height $(\mathrm{PH})$, substrate electrical conductivity (EC), number of leaves (NL), shoot dry mass (SDM), total dry mass (TDM) and root length (RL) showed no significant difference $(\mathrm{P}>0.05)$. For collar diameter $(\mathrm{CD})$, no treatment differed from the control, except for T5. For root dry mass (RDM), the treatments $\mathrm{T} 1$ and $\mathrm{T} 3 \mathrm{did}$ not differ from the control and, in the case of the Dickson Quality Index (DQI), only T1 did not differ 
from the control. From the treatment T2, the DQI was compared to the control (Table 8).

values were statistically lower when each treatment

Table 8. Means of the variables analyzed in okra seedlings and substrate, at 18 DAS, as a function of treatments containing increasing levels of grape pomace (GP)/decreasing levels of commercial substrate (T1 to T6) and the exclusive use of commercial substrate (T0).

\begin{tabular}{lcccccccccc}
\hline $\begin{array}{l}\text { TREATMENT } \\
\text { RV/CS }\end{array}$ & $\begin{array}{c}\mathrm{pH} \\
(\mathrm{cm})\end{array}$ & $\begin{array}{c}\mathrm{CD} \\
(\mathrm{mm})\end{array}$ & $\mathrm{pH}$ & $\begin{array}{c}\mathrm{EC}^{-1} \\
\left(\mathrm{dS} \mathrm{m}^{-1}\right)\end{array}$ & $\mathrm{NL}^{*}$ & $\begin{array}{c}\mathrm{SDM}^{*} \\
(\mathrm{~g})\end{array}$ & $\begin{array}{c}\mathrm{RDM}^{*} \\
(\mathrm{~g})\end{array}$ & $\begin{array}{c}\mathrm{TDM}^{*} \\
(\mathrm{~g})\end{array}$ & $\begin{array}{c}\mathrm{RL}^{*} \\
(\mathrm{~cm})\end{array}$ & $\mathrm{DQI}^{*}$ \\
\hline $0 / 100 \%(\mathrm{~T} 0)$ & 8.85 & $2.13 \mathrm{~A}$ & $4.72 \mathrm{~B}$ & 0.423 & 3.22 & 0.1 & $0.024 \mathrm{~A}$ & 0.13 & 4.88 & $0.0150 \mathrm{~A}$ \\
$10 / 90 \%(\mathrm{~T} 1)$ & 8.67 & $2.14 \mathrm{~A}$ & $5.57 \mathrm{~A}$ & 0.425 & 3.05 & 0.09 & $0.023 \mathrm{~A}$ & 0.12 & 5.02 & $0.0140 \mathrm{~A}$ \\
$20 / 80 \%(\mathrm{~T} 2)$ & 8.82 & $2.10 \mathrm{~A}$ & $6.30 \mathrm{~A}$ & 0.365 & 3.11 & 0.11 & $0.018 \mathrm{~B}$ & 0.12 & 4.6 & $0.0121 \mathrm{~B}$ \\
$30 / 70 \%(\mathrm{~T} 3)$ & 9.3 & $2.12 \mathrm{~A}$ & $6.53 \mathrm{~A}$ & 0.371 & 3.22 & 0.1 & $0.024 \mathrm{~A}$ & 0.12 & 5.67 & $0.0144 \mathrm{~B}$ \\
$40 / 60 \%(\mathrm{~T} 4)$ & 8.44 & $2.00 \mathrm{~A}$ & $6.95 \mathrm{~A}$ & 0.511 & 3.11 & 0.11 & $0.015 \mathrm{~B}$ & 0.12 & 5.59 & $0.0107 \mathrm{~B}$ \\
$50 / 50 \%(\mathrm{~T} 5)$ & 7.95 & $1.76 \mathrm{~B}$ & $7.10 \mathrm{~A}$ & 0.428 & 2.94 & 0.08 & $0.014 \mathrm{~B}$ & 0.1 & 5.04 & $0.0091 \mathrm{~B}$ \\
\hline $\mathrm{P}$ value & 0.5478 & 0 & 0 & 0.5531 & 0.156 & 0.156 & 0.002 & 0.156 & 0.058 & 0.012 \\
$\mathrm{CV}$ & $14.17 \%$ & $4.90 \%$ & $3.68 \%$ & $34.11 \%$ & $6.10 \%$ & $32.13 \%$ & $25.36 \%$ & $84.64 \%$ & $14.29 \%$ & $21.82 \%$ \\
\hline
\end{tabular}

Uppercase letters in each column compare each of the treatments with the control by Dunnett's test at 5\% probability level.

*Uppercase letters in each column compare each of the treatments with the control by the signal test at 5\% probability level (response variables that did not meet mainly the assumption of homoscedasticity).

Based on the same criterion of substrate recommendation for pumpkin, i.e., with DQI as an important parameter of seedling quality, the substrate containing $10 \%$ grape pomace and $90 \%$ commercial substrate is more appropriate for the production of okra seedlings, since this treatment did not differ statistically from the control (Table 8).

Marques et al. (2018), when testing different substrates from the composting of organic residues, found higher values of the variables analyzed, when compared to those obtained in this study. However, it should be considered that the authors performed the analyses at $30 \mathrm{DAS}$, hence a longer time when compared to that of the present experiment, which enabled the seedlings to show better development.

It is believed that the decreasing values of SDM and TDM in pumpkin seedlings and RDM and DQI in okra seedlings, with the increment of residue in the substrate, may be associated with the presence of some constituents in the pomace, which may have affected the development of the seedlings. According to Rockenbach et al. (2011), the peels contain a large amount of phenolic compounds, including anthocyanins, hydroxycinnamic acids, catechins and flavonols. Tonon et al. (2018) state that the use of grape biomass as fertilizer can cause some problems as it enables the release of phytotoxic compounds, namely phenols and tannins, and increases the contents of copper, zinc and manganese. These effects can lead to phytotoxicity problems, with negative effects on vegetative development. These authors suggest that, in order to minimize these effects, grape biomass needs to be composted before being applied to the soil.
In addition to the presence of phenols and tannins contained in the pomace, some constituents present in peels and seeds may have hampered the mineralization of the residues by microorganisms and consequently affected the availability of nutrients to the seedlings.

According to Beres et al. (2017), the peels have $90 \%$ of insoluble fibers, which comprise cellulose, certain hemicelluloses and lignin. In the seeds, it is also possible to find fibers distributed among cellulose, hemicellulose and lignin (CHAMORRO et al., 2012), in addition to polyunsaturated fatty acids (PUFAs), with linoleic acid being the most concentrated fatty acid, representing about 66 to $73 \%$ of the total (GARAVAGLIA et al., 2016).

According to Kiehl (1985), cellulose and some hemicelluloses are decomposed more slowly and by specific organisms. Lignin, certain greases and tannins are considered more resistant to decomposition. Cotrufo, Galdo and Piermatteo (2009) warn that, in regard to the cycling, there are variations in nutrient release by the decomposition process, which in turn is influenced by edaphoclimatic conditions and the quality (nutrients, cellulose, hemicellulose and lignin) of the deposited residue. Thus, high temperature and moisture tend to increase waste decomposition rates, while large amounts of lignin reduce them. The authors state that lignin is the component with the greatest interference on the decomposition process, since it is a material widely known to be more recalcitrant. In the case of tannins, Bhat, Singh and Sharma (1998) state that these compounds are more difficult to be hydrolyzed and can be toxic to both animals 
and a wide variety of microorganisms. This may explain the effect of condensed tannins in slowing biodegradation and decreasing the decomposition of organic matter.

Thus, it is possible that treatments with lower proportions of vitiviniculture residues were not affected regarding the availability of nutrients, compared to those with higher proportions.

Although the $\mathrm{pH}$ of vitiviniculture residues was relatively low (Table 3), when these were mixed with the commercial substrate, there were increments of $\mathrm{pH}$ values in the experiments carried out with the two crops, which led to a $\mathrm{pH}$ above ideal in the mixture at the higher proportions. For the $\mathrm{pH}$ value in water, Kämpf (2005) describes nine ranges, from extremely low $(<4.5)$ to extremely high ( $>6.9$ ), considering the range from 5.2 to 5.5 as optimal for substrates without mineral soil. In this case, only the treatments $\mathrm{T} 0$ and $\mathrm{T} 1$ for pumpkin and $\mathrm{T} 1$ for okra are within the ideal $\mathrm{pH}$ range (Tables 7 and 8). Thus, the high $\mathrm{pH}$ may also have hampered the development of the seedlings, especially those of okra. According to Martinez (2004), the indirect effect of $\mathrm{pH}$ refers to the solubility of nutrients, which may precipitate at $\mathrm{pH}$ higher than 6.0 and no longer be available to plants, especially nitrogen, which is closely related to the formation of chlorophyll molecules.

\section{CONCLUSIONS}

According to the obtained results, it is concluded that:

The substrate composed of coffee chaff and organic compost has a high potential to be used as an alternative substrate due to promote better quality of papaya seedlings compared to the commercial substrate.

Alternative substrate containing $60 \%$ coffee chaff and $40 \%$ organic compost is recommended for the production of Formosa papaya seedlings in tubes.

The grape pomace (GP) has a high potential to be used as component in the substrate for the production of okra and zucchini seedlings compared to the commercial substrate (CS) only.

Alternative substrate composed of $50 \%$ GP and $50 \% \mathrm{CS}$ is recommended for the production of zucchini seedlings, while substrate composed of $10 \%$ GP and $90 \%$ CS is recommended for the production of okra seedlings.

\section{ACKNOWLEDGMENTS}

The authors thank PRODIF for the financial support in the translation of this manuscript.

RESUMO: A utilização de resíduos advindos da agricultura apresenta-se como uma alternativa interessante do ponto de vista econômico, para a obtenção de mudas, além de ser uma forma de diminuir os impactos ambientais causados pelo descarte inadequado destes resíduos no ambiente. Objetivou-se avaliar a potencialidade de utilização da moinha de café e composto orgânico como componentes de substratos para produção de mudas de mamão Formosa, e a potencialidade dos resíduos da vitivinicultura como componentes de substratos para produção de mudas de abóbora e quiabo. Na produção de mudas de mamão formosa, o experimento foi realizado no delineamento inteiramente casualizado (DIC), com sete tratamentos e seis repetições, sendo: $\mathrm{T} 0=100 \%$ de substrato comercial Bioplant ${ }^{\circledR}(\mathrm{SC})$, e do $\mathrm{T} 1$ ao $\mathrm{T} 6$, proporções crescentes de moinha de café (MC) e decrescentes de composto orgânico (CO): 10/90; 20/80; 30/70; 40/60; 50/50 e 60/40\%. $\mathrm{Na}$ produção de mudas de abóbora e quiabo, o experimento foi realizado no delineamento inteiramente casualizado (DIC), com seis tratamentos e seis repetições, sendo proporções crescentes de bagaço de uva (BU) e decrescentes de substrato comercial (SC): 0/100; 10/90; 20/80; 30/70; 40/60 e 50/50\%. Aos 59 DAS foram avaliados o número de folhas, altura da muda, diâmetro do caule, massa de matéria seca da parte aérea, radicular e total da muda e o Índice de Qualidade de Dickson (IQD) em mudas de mamão formosa. As avaliações nas mudas de abóbora e quiabo foram realizadas aos 12 e 18 DAS, respectivamente, e as variáveis analisadas foram o número de folhas, altura da planta, comprimento da raiz, diâmetro do coleto, massa seca da parte aérea, massa seca da raiz, massa seca total e o IQD. O substrato composto por moinha de café e composto orgânico possui elevado potencial de uso em razão de promover melhor qualidade de mudas de mamoeiro quando comparado com o substrato comercial. Recomenda-se o substrato alternativo contendo $60 \%$ de moinha de café e $40 \%$ de composto orgânico, em substituição ao substrato convencional, na produção de mudas de mamão Formosa em tubetes. O bagaço de uva possui elevado potencial para ser usado como componente de substrato na produção de mudas de abóbora e quiabo quando comparado com o uso isolado do substrato comercial. Para produção de mudas de abóbora recomenda-se o uso do substrato composto por $50 \%$ de BU e $50 \%$ de SC, já para a produção de mudas de quiabo recomenda-se um substrato composto por $10 \%$ de BU e $90 \%$ de SC. 
PALAVRAS-CHAVE: Composto orgânico. Moinha de café. Vitivinicultura.

\section{REFERENCES}

ALMEIDA, K. M.; LO MONACO, P. A. V.; KRAUSE, M. R.; VALLE, J. M.; MENEGHELLI, L. A. M.; VIEIRA, G. H. S.; GUISOLFI, L. P. Use of Coffee Moinha, Commercial Substrate, Carbonized Rice Husk, Coconut Fiber and Eggshel in the Composition of Alternative Substrates for Melon Seedlings Production. Journal of Experimental Agriculture International, v.21, n.4, p.1-9, 2018a. https://doi.org/10.9734/JEAI/2018/39792

ALMEIDA, W. A. de; UCHÔA, T. L.; SOUZA, L. G. de S.; SILVA, N. M. da; NETO, S. E. A. Aumento da qualidade de mudas de mamoeiro com substrato à base de resíduos. Pesquisa Aplicada \& Agrotecnologia, v.11, n.3, p.113-119, 2018b. http://doi.org/10.5935/PAeT.V11.N3.11

ARAÚJO, E. F.; ARAUCO, A. M. S.; LACERDA, J. J. J.; RATKE, R.F.; MEDEIROS, J.C. Crescimento e balanço nutricional de mudas de Enterolobium contortsiliquum com aplicação de substratos orgânicos e água residuária. Pesquisa Florestal Brasileira, v. 36, n. 86, p. 169-177, 2016.

https://doi.org/10.4336/2016.pfb.36.86.1135

BERES, C.; COSTA, G. N. S.; CABEZUDO, I.; SILVA; JAMES, N. K.; TELES, A. S. C.; CRUZ, A. P. G.; MELLINGER-SILVA, C.; TONON, R. V.; CABRAL,L. M. C.; FREITAS, S. P. Towards integral utilization of grape pomace from wine making process: a review. Waste Management. v. 68, p. 581-594, 2017.

https://doi.org/10.1016/j.wasman.2017.07.017

BERILLI, S. S.; CARVALHO, A. D.; FREITAS, S. de J.; FARIA, D. C.; MARINHO, C. Avaliação do desenvolvimento de diferentes tamanhos de mudas micropropagadas de abacaxizeiro, após

aclimatação. Revista Brasileira de Fruticultura, v. 33, n. 1, p. 208-214, 2011. https://doi.org/10.1590/S010029452011005000018

BHAT, T. K.; SINGH, B.; SHARMA, O. P. Microbial degradation of tannins - A current perspective. Biodegradation, v. 9, p.343-357, 1998. https://doi.org/10.1023/A:1008397506963

CARDOSO, A. I. I.; FERREIRA, K. P.; VIEIRA JÚNIOR, R. M.; ALCARDE, C. Alterações em propriedades do solo adubado com composto orgânico e efeito na qualidade das sementes de alface. Horticultura Brasileira, v.29, n. 4, p. 594-599, 2011. https://doi.org/10.1590/S0102-05362011000400025

CARMONA, E.; MORENO, M. T.; AVILÉS, M.; ORDOVÁS, J. Use of grape marc compost as substrate for vegetable seedlings. Scientia Horticulturae, v.137, p.69-74, 2012.

https://doi.org/10.1016/j.scienta.2012.01.023

CAVINS, T. J.; WHIPKER B. E.; FONTENO, W. C.; HARDEN, B.; McCALL, I.; GIBSON, J. L. Monitoring and managing $\mathrm{pH}$ and $\mathrm{EC}$ using the Pour Thru Extraction Method. Horticulture Information Leaflet. Raleigh: NCSU. 2000. 17 p. Disponível em: <

https://projects.ncsu.edu/project/hortsublab/pdf/PourThru_Master_HIL.pdf >. Acesso em: 20 Nov. 2020.

CHAMORRO, S.; VIVEROS, A.; ALVAREZ, I.; VEGA, E.; BRENES, A. Changes in polyphenol and polysaccharide content of grape seed extract and grape pomace after enzymatic treatment. Food Chemistry, v. 133, n. 2, p. 308-314, 2012. https://doi.org/10.1016/j.foodchem.2012.01.031

COSTA JUNIOR, E. de S.; MATIAS, S. S. R.; MORAIS, D. B. de; SOUSA, S. J. de C.; SANTOS, G. B. dos; NASCIMENTO, A. H. do. Produção de mudas de Carica papaya, tipo formosa, com resíduos de pau de buriti (Mauritia flexuosa L.f.). Revista de Ciências Agrárias, v. 40, n. 4, p. 746-755, 2017.

https://doi.org/10.19084/RCA16152 
COSTA, J. C. F. da; MENDOÇA, R. M. N.; FERNANDES, L. F. OLIVEIRA, F. P. de; SANTOS, D. Caracterização física de substratos orgânicos para o enraizamento de estacas de goiabeira. Revista Brasileira de Agropecuária Sustentável, v.7, n. 2, p. 16-23, 2017. https://doi.org/10.21206/rbas.v7i2.390

COTRUFO, F. C.; GALDO, I. D.; PIERMATTEO, D. Litter decomposition: concepts, methods and future perspectives. In: KUTSCH, W.L.; BAHN, M.; HEINEMEYER, A. (Ed.). Soil carbon dynamics: an integrated methodology. Cambridge: University Press, 2009. p. 76-90.

https://doi.org/10.1017/CBO9780511711794

CUNHA, T. J. F.; MENDES, A. M. S.; GIONGO, V. Matéria orgânica do solo. In: NUNES, R. R.; REZENDE, M. O. O. (Org.). Recurso solo: propriedades e usos. São Carlos: Embrapa Semiárido, 2015. p. 273-293. Disponível em < https://ainfo.cnptia.embrapa.br/digital/bitstream/item/137613/1/Tony-2015.pdf $>$. Acesso em: 20 Nov. 2020.

DICKSON, A.; LEAF, A. L.; HOSNER, J. F. Quality appraisal of white spruce and white pine seedling stock in nurseries. The Forestry Chronicle, v. 36, n. 1, p. 10-13, 1960. https://doi.org/10.5558/tfc36010-1

DUARTE, R. F.; SAMPAIO, R. A.; BRANDÃO JÚNIOR, D. da S.; FERNANDES, L. A.; SILVA, H. P. da. Crescimento inicial de Acácia em condicionador formado de fibra de coco e resíduo agregante. Revista Brasileira de Engenharia Agrícola e Ambiental, v.14, n.11, p.1176-1185, 2010. https://doi.org/10.1590/S1415-43662010001100007

ECHER, M. M.; GUIMARÃES, V. F.; ARANDA, A. N.; BORTOLAZZO, E. D.; BRAGA, J. S. Avaliação de mudas de beterraba em função do substrato e do tipo de bandeja. Semina: Ciências Agrárias, v. 28, n. 1, p. 45-50. 2007. https://doi.org/10.5433/1679-0359.2007v28n1p45

ESPÍRITO SANTO/SECRETARIA DE ESTADO DA AGRICULTURA, ABASTECIMENTO, AQUICULTURA E PESCA. Pedeag 3: Plano Estratégico de Desenvolvimento da Agricultura Capixaba Espírito Santo sustentável. 2016. 206 p. Disponível

em: $<$ https://seag.es.gov.br/Media/seag/Documentos/PEDEAG_Completo_sem\%20ficha\%20t\%C3\%A9cnica\% 20(1).pdf>. Acesso em: 13 Jul. 2020.

GALO, J. Q. B.; SOUZA, M. L. de; KUSDRA, J. F.; MATTIUZ, C. F. M. Conservação pós-colheita de mamão 'Sunrise Solo' com uso de quitosana. Revista Brasileira de Fruticultura, v. 36, n. 2, p. 305-312, 2014. https://doi.org/10.1590/0100-2945-194/13

GARAVAGLIA J.; MARKOSKI, M. M.; OLIVEIRA, A.; MERCADENTI, A. Grape seed oil compounds: Biological and chemical actions for health. Nutrition and metabolic insights, v. 9, p. 59-64, 2016. https://doi.org/10.4137\%2FNMI.S32910

GIMENES, F. M. de A.; BARBOSA, H. Z.; GERDES, L.; GIACOMINI, A. A.; MATTOS, W. T. de; BATISTA, K.; PREMAZZI, L. M.; MIGUEL, A. N. de V. The utilization of tropical legumes to provide nitrogen to pastures: a review. African Journal of Agricultural Research, v. 12, n. 2, p. 85-92, 2017. https://doi.org/10.5897/AJAR2016.11893

GUIMARÃES, I. P.; PAIVA, E. P.; ALMEIDA, J. P. N.; ARRAIS, I. G.; CARDOSO, E. A.; SÁ, F. V. S. Produção de mudas de três acessos de mamoeiro sob doses do bioestimulante Root ${ }^{\circledR}$. Revista de Ciências Agrárias, v.38, n.3, p. 414-421, 2015. Disponível em:

$<$ http://www.scielo.mec.pt/pdf/rca/v38n3/v38n3a16.pdf>. Acesso em: 20 Nov. 2020.

GUISOLFI, L. P.; LO MONACO, P. A. V.; HADDADE, I. R.; KRAUSE, M. R.; MENEGHELLI, L. A. M.; ALMEIDA, K. M. Production of cucumber seedlings in alternative substrates with different compositions of agricultural residues. Revista Caatinga, v. 31, n. 3, p. 791-797, 2018. https://doi.org/10.1590/1983$21252018 \mathrm{v} 3 \ln 330 \mathrm{rc}$ 
GUISOLFI, L. P.; LO MONACO, P. A. V.; KRAUSE, M. R.; MENEGHELLI, C. M.; ALMEIDA, K. M.; MENEGHELLI, L. A. M.; VIEIRA, G. H. S. Agricultural wastes as alternative substrates in the production of conilon coffee seedlings. Bioscience Journal, v. 36, n. 3, p. 792-798, 2020. http://dx.doi.org/10.14393/BJv36n3a2020-47718

HIGUTI, A. R. O.; SALATA, A. C.; GODOY, A. R.; CARDOSO, A. I. I. Produção de mudas de abóbora com diferentes doses de nitrogênio e potássio. Bragantia, v. 69, n. 2, p. 377-380. 2010.

https://doi.org/10.1590/S0006-87052010000200016

KÄMPF, A. N. Produção comercial de plantas ornamentais. Guaíba: Agropecuária, 2005. 256 p.

KRAUSE, M. R.; LO MONACO, P. A. V.; HADDADE, I. R.; MENEGHELLI, L. A. M.; SOUSA, T. D. Aproveitamento de resíduos agrícolas na composição de substratos para produção de mudas de tomateiro. Horticultura Brasileira, v. 35, n. 2, p. 293-298, 2017. https://doi.org/10.1590/s0102-053620170224

KIEHL, E. J. Fertilizantes orgânicos. São Paulo: Editora Agronômica Ceres. 1985. 492 p.

LO MONACO, P. A. V.; DE OLIVEIRA, D. L. S.; HADDADE, I. R.; KRAUSE, M. R.; ALMEIDA, K. M.; MENEGHELLI, L. A. M.; VIEIRA, G. H. S. Optimum Substitution of Commercial Substrate with Moinha as an Alternative Biodegradable Agricultural Waste Substrate in the Production of Beet Seedlings. Journal of Experimental Agriculture International, v. 24, n. 6, p. 1-9, 2018. https://doi.org/10.9734/JEAI/2018/42718

LO MONACO, P. A. V.; VIEIRA, J. C.; COLOMBO, J. N.; KRAUSE, M. R.; VIEIRA, G. H. S.; ALMEIDA, K. M. Use of agricultural waste material as an alternative substrate in cabbage seedling production and development. Emirates Journal of Food and Agriculture, v. 32, n. 2, p.131-139, 2020.

https://doi.org/10.9755/ejfa.2020.v32.i2.2071

MARQUES, C. S.; GUIMARÃES, P. V. P.; SOUSA, R. C. P.; MATTIONI, J. M.; SMIDERLE, O. J. Seleção de substratos da compostagem de resíduos orgânicos para o desenvolvimento inicial de quiabeiro. Cadernos de agroecologia, v.13, n.1, 2018. Disponível em: <http://cadernos.abaagroecologia.org.br/index.php/cadernos/article/view/1864>. Acesso em: 20 Nov. 2020.

MARTINEZ, H. E. P. Distúrbios nutricionais em hortaliças cultivadas em substratos com baixa atividade química. In: BARBOSA, J.G.; MARTINES, H.E.P.; PEDROSA, M.W.; SEDIYAMA, M.A.N. (Eds.). Nutrição e Adubação de Plantas Cultivadas em Substratos. Viçosa: UFV, 2004, p.129- 157.

MATOS, A. T. Manual de análise de resíduos sólidos e águas residuárias. $1^{\text {a }}$ ed. Viçosa: Editora UFV, 2015. 149p.

MELO, A. S.; COSTA, C. X.; BRITO, M. E. B.; VIÉGAS, P. R. A.; SILVA JÚNIOR, C. D. Produção de mudas de mamoeiro em diferentes substratos e doses de fósforo. Revista Brasileira de Ciências Agrárias, v. 2, n. 4, p. 257-261, 2007. Disponível em: <http://www.agraria.pro.br/ojs-

2.4.6/index.php?journal $=$ agraria\&page $=$ article $\& o p=$ view $\&$ path $\% 5 \mathrm{~B} \% 5 \mathrm{D}=1838 \&$ path $\% 5 \mathrm{~B} \% 5 \mathrm{D}=3471>$. Acesso em: 20 Nov. 2020.

MENDONÇA, V.; ABREU, N. A. A. de; SOUZA, H. A. de; FERREIRA, E. A.; RAMOS, J. D. Diferentes níveis de composto orgânico na formulação de substrato para a produção de mudas de mamoeiro 'formosa'. Revista Caatinga, v. 20, n. 1, p. 49-53, 2007. Disponível em:

$<$ https://periodicos.ufersa.edu.br/index.php/caatinga/article/view/111>. Acesso em: 20 Nov. 2020.

MENEGHELLI, L. A. M.; LO MONACO, P. A. V.; HADDADE, I. R.; MMENEGHELLI, C. M.; ALMEIDA, K. M. Agricultural residues as a substrate in the production of eggplant seedlings. Horticultura Brasileira, v. 35, n. 4, p. 527-533, 2017. https://doi.org/10.1590/s0102-053620170409 
MENEGHELLI, C. M.; MONACO, P. A. V. L.; HADDADE, I. R.; MENEGHELLI, L. A. M.; KRAUSE, M. R. Resíduo da secagem dos grãos de café como substrato alternativo em mudas de café Conilon. Coffee Science, v. 11, n. 3, p. 329-334, 2016. Disponível em:

$<$ http://www.coffeescience.ufla.br/index.php/Coffeescience/article/view/1086/1086_2>. Acesso em: 20 Nov. 2020.

MENEGHELli, L. A. M.; LO MONACO, P. A. V.; HADDADE, I. KRAUSE, M. R.; MENEGHELLI, C. M.; GUISOLFI, L. P.; MENEGASSI, J. Resíduos agrícolas incorporados a substrato comercial na produção de mudas de repolho. Revista Ciências Agroveterinárias, v. 17, n. 4, p. 491-497, $2018 \mathrm{~b}$.

http://dx.doi.org/10.5965/223811711732018491

MENEGHELLI, L. A. M.; MONACO, P. A. V. L.; KRAUSE, M. R.; GUISOLFI, L. P.; ALMEIDA, K. M.; VALLE, J. M., VIEIRA, G. H. S. Utilization of Agricultural Residues as Alternative Substrates in the Production of Conilon Coffee Seedlings. Journal of Experimental Agriculture International, v. 21, n. 4, p. 1-6, 2018a. https://doi.org/10.9734/JEAI/2018/39797

OLIVEIRA, A. C.; BISCARO, G. A.; SILVA, E. A.; SILVA, V. L. Production of papaya (Carica papaya 1.) With nitrogen and sulfur doses. Scientific electronic archives, v. 11, n. 6, p. 17-25, 2018. Disponível em: < https://sea.ufr.edu.br/index.php?journal=SEA\&page=article\&op=download\&path $\% 5 \mathrm{~B} \% 5 \mathrm{D}=581 \&$ path $\% 5 \mathrm{~B} \% 5$ $\mathrm{D}=\mathrm{pdf}>$. Acesso em: 20 Nov. 2020.

OLIVEIRA, A. B.; HERNANDEZ, F. F. F.; ASSIS JÚNIOR, R. N. Pó de coco verde, uma alternativa de substrato na produção de mudas de berinjela. Revista Ciência Agronômica, v. 39, n. 1, p. 39-44, 2008. Disponível em: $<$ http://ccarevista.ufc.br/seer/index.php/ccarevista/article/view/22/21>. Acesso em: 20 Nov. 2020.

OLIVEIRA, F. S. de; FARIAS, O. R. de; NOBRE, R. G.; FERREIRA, I. B.; FIGUEREDO, L. C. de; OLIVEIRA, F. S. de. Produção de mudas de mamoeiro 'Formosa' com diferentes doses de esterco ovino. Revista de Ciências Agrárias, v. 58, n. 1, p. 52-57, 2015. http://dx.doi.org/10.4322/rca.1731

OLIVEIRA JÚNIOR, O. A.; CAIRO, P. A. R.; NOVAES, A. B. Características morfofisiológicas associadas à qualidade de mudas de Eucalyptus urophylla produzidas em diferentes substratos. Revista Árvore, v. 35, n. 6 , p. 1173-1180, 2011. https://doi.org/10.1590/S0100-67622011000700003

PEREIRA, D. C.; GRUTZMACHER, P.; BERNARDI, F. H.; MALLMANN, L. S.; COSTA, L. A. M.; COSTA, M. S. S. M. 2012. Produção de mudas de almeirão e cultivo no campo, em sistema agroecológico. Revista Brasileira de Engenharia Agrícola e Ambiental, v. 16, n.10, p. 1100-1106, 2012. https://doi.org/10.1590/S1415-43662012001000010

PEREIRA, P. C.; MELO, B. D.; FREITAS, R. D.; TOMAZ, M. A.; FREITAS, C. D. J. Mudas de tamarindeiro produzidas em diferentes níveis de matéria orgânica adicionada ao substrato. Revista Verde de Agroecologia e Desenvolvimento Sustentável, v. 5, n. 3, p. 152-159, 2010. Disponível em:

$<$ https://www.gvaa.com.br/revista/index.php/RVADS/article/view/318>. Acesso em: 12 Ago. 2020.

PINHEIRO, F. W. A.; NOBRE, R. G.; SOUZA, L. P.; OLIVEIRA, S. G. de; ARAÚJO, J. E. S.; VELOSO, L. L. D. S. A. Irrigação com águas salinas e adubação nitrogenada na produção de mudas mamoeiro "Formosa". Revista Verde de Agroecologia e Desenvolvimento Sustentável, v. 12, n. 1, p. 17-22, 2017. http://dx.doi.org/10.18378/rvads.v12i1.4754

PINTER, I. F.; AGUADO, G. D.; DE BIASI, F.; FERNÁNDES, A. S.; MARTINEZ, L.; ULIARTE, E. M. Performance of grape marc and organic residues compost as substrate in lettuce (Lactuca sativa) seedlings.

Revista de la Facultad de Ciencias Agrarias, v. 51, v. 2, p. 261-269, 2019. Disponível em: $<$ http://revistas.uncu.edu.ar/ojs/index.php/RFCA/article/view/2694>. Acesso em: 5 Out. 2020. 
R Core Team. R: A language and environment for statistical computing. Vienna: R Foundation for Statistical Computing, 2019. Available at: <https://www.r-project.org/>. Acesso em: 3 Dez. 2019.

ROCKENBACH, I. I.; RODRIGUES, E.; GONZAGA, L. V.; CALIARI, V.; GENOVESE, M. I.; GONÇALVES, A. E. S. S.; FETT, R. Phenolic compounds content and antioxidant activity in pomace from selected red grapes (Vitis vinifera L. and Vitis labrusca L.) widely produced in Brazil. Food Chemistry, v. 127, n. 1, p. 174-179, 2011. https://doi.org/10.1016/j.foodchem.2010.12.137

RUGGIERI, L.; CADENA, E.; MARTINEZ-BLANCO, J.; GASOL, C. M.; RIERADEVALL, J.; GABARRELL, X.; GEA, T.; SORT, X.; SÁNCHEZ, A. Recovery of organic wastes in the Spanish wine industry. Technical, economic and environmental analyses of the composting process. Journal of Cleaner Production, v. 17, n. 1, p. 830-838, 2009. https://doi.org/10.1016/j.jclepro.2008.12.005

SALLES, J. S.; LIMA, A. H. F.; COSTA, E.; BINOTTI, E. D. C.; BINOTTI, F. F. S. Papaya seedling production under different shading levels andsubstrate compositions. Engenharia Agrícola, v. 39, n. 6, p. 698706, 2019. https://doi.org/10.1590/1809-4430-eng.agric.v39n6p698-706/2019

SANTOS, C. B.; LONGHI, S. J.; HOPPE, J. M.; MOSCOVICH, F. A. Efeito do volume de tubetes e tipos de substratos na qualidade de mudas de Cryptomeria japonica (L.F.) D. Don. Ciência Florestal, v. 10, n. 2, p. 115, 2000. https://doi.org/10.5902/19805098466

SARAIVA, K. R.; NASCIMENTO, R. S.; SALES, F. A. L.; ARAÚJO, H. F.; FERNANDES, C. N. V.; LIMA, A. D. Produção de mudas de mamoeiro sob doses de adubação fosfatada utilizando como fonte superfosfato simples. Revista Brasileira de Agricultura Irrigada, v. 5, n. 4, p. 376-383, 2011.

https://doi.org/10.7127/RBAI.V5N400065

SCHAFFER, N.: TORNIQUIST, C. G.; MANFROI, V. Resíduos de vinificação com potencial de uso agrícola. In: CONGRESSO BRASILEIRO DE CIÊNCIA DO SOLO, 34, 2013, Florianópolis. Anais... Florianópolis: SBCS, 2013. p. 1-4.

SCHOCK, A. A.; RAMM, A.; MARTINAZZO, E. G.; SILVA, D. M.; BACARIN, M. A. Crescimento e fotossíntese de plantas de pinhão-manso cultivadas em diferentes condições de luminosidade. Revista brasileira de engenharia agrícola e ambiental, v. 18, n. 1, p. 3-9, 2014. https://doi.org/10.1590/S141543662014000100001

SILVA, S. S.; CAVALCANTE, M. Z. B.; DULTRA, D. F. S.; BRITO, L. P. S. Uso de resíduos orgânicos decompostos como substrato para produção de mudas de alface: efeito no sistema radicular. Revista de La Facultad de Agronomía, v. 117, n. 2, p. 245-252, 2018a. Disponível em:

$<$ https://revistas.unlp.edu.ar/revagro/article/view/7341>. Acesso em: 5 Set. 2020.

SILVA, W.; OLIVEIRA, A.; SILVA, V., RIBEIRO, C.; LUZ, W. Formação de mudas de mamoeiro formosa sob diferentes substratos orgânicos em Nova Xavantina-MT. Cadernos de Agroecologia, v. 13, n. 1, 2018 b. Disponível em: <http://cadernos.aba-agroecologia.org.br/index.php/cadernos/article/view/1295>. Acesso em: 6 Set. 2020.

SIMÕES, A. C.; ALVES, G. K.; FERREIRA, R. L.; NETO, A.; SEBASTIÃO, E. Qualidade da muda e produtividade de alface orgânica com condicionadores de substrato. Horticultura Brasileira, v. 33, n. 4, p. 521-526, 2015. https://doi.org/10.1590/S0102-053620150000400019

SMIDERLE, O. J.; SOUZA, A. G. Production and quality of Cinnamom umzeylanicum Blume seedlings cultivated in nutrient solution. Revista Brasileira de Ciências Agrárias, v.11, n.2, p. 104-110, 2016. https://doi.org/10.5039/agraria.v11i2a5364 
SOUSA, S. M., GOMES, E. A., DE SOUZA, F. A., DE VASCONCELOS, M. J. V. Importância da morfologia radicular na eficiência da aquisição de fósforo. Sete Lagoas: Embrapa Milho e SorgoDocumentos (INFOTECA-E), 105, 2010. 33p. Disponível em:

$<$ http://ainfo.cnptia.embrapa.br/digital/bitstream/item/26840/1/Doc-105.pdf > . Acesso em: 5 Nov. 2020.

SOUZA, R. R.; MATIAS, S. S. R.; SILVA, R. R.; SILVA, R. L. BARBOSA, J. S. M. Qualidade de mudas de mamão produzidas em substrato com esterco caprino e doses de superfosfato simples. Revista Agrarian, v. 8, n. 28, p. 139-146, 2015. Disponível em: <http://ojs.ufgd.edu.br/index.php/agrarian/article/view/2713>. Acesso em: 15 Nov. 2020.

TAIZ, L.; ZEIGER, E. Fisiologia vegetal. 5a ed. Porto Alegre: Editora Artmed, 2013. 918 p.

TONON, R. V.; SILVA, C. M.; GALDEANO, M. C.Ç; SANTOS, K. M. O. Tecnologias para o aproveitamento integral dos resíduos da indústria vitivinícola. Rio de Janeiro: Embrapa Agroindústria de Alimentos, Documentos 132, 2018. 41p. Disponível em <https://www.embrapa.br/busca-de-publicacoes//publicacao/1105247/tecnologias-para-o-aproveitamento-integral-dos-residuos-da-industria-vitivinicola. Acesso em: 09 Mar. 2020.

WAGNER JÚNIOR, A.; NEGREIROS, J. R. S.; ALEXANDRE, R. S.; PIMENTEL, L. D.; MORGADO, L. A. D.; BRUCKNER, C. H. Substratos no desenvolvimento inicial de quatro cultivares de pessegueiro e uma nectarineira. Ciência e Agrotecnologia, v.32, n.4, p.1322-1328, 2008. https://doi.org/10.1590/S141370542008000400045

WERADUWAGE, S. M.; CHEN, J.; ANOZIE, F. C.; MORALES, A.; WEISE, S. E.; SHARKEY, T. D. The relationship between leaf area growth and biomass accumulation in Arabidopsis thaliana. Frontiers in Plant Science, v. 6, n. 167, p.1-21, 2015. https://doi.org/10.3389/fpls.2015.00167

ZHANG, N.; HOADLEY, A.; PATEL, J.; LIM, S.; LI, C. Sustainable options for the utilization of solid residues from wine production. Waste management, v. 60, p. 173-183, 2017.

https://doi.org/10.1016/j.wasman.2017.01.006

ZOCCA, F.; LOMOLINO, G.; CURIONI, A.; SPETTOLI, P.; LANTE, A. Detection of pectinmethylesterase activity in presence of methanol during grape pomace storage. Food Chemistry, v. 102, n. 1, p. 59-65, 2007. https://doi.org/10.1016/j.foodchem.2006.01.061 